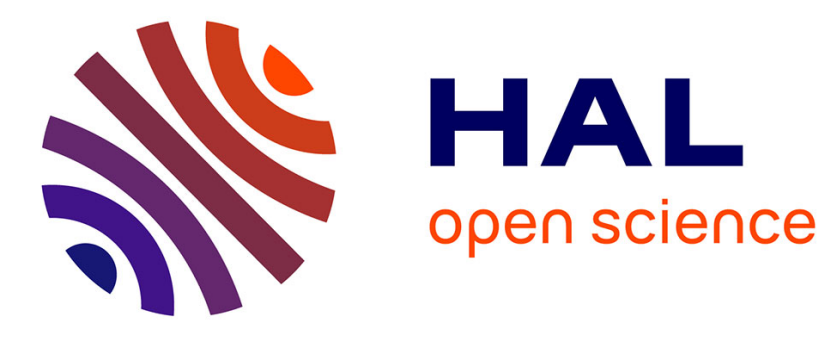

\title{
Production of poly(3-hydroxybutyrate-3-hydroxyvalerate) by from waste rapeseed oil using propanol as a precursor of 3-hydroxyvalerate
}

Stanislav Obruca, Ivana Marova, Ondrej Snajdar, Ludmila Mravcova, Zdenek Svoboda

\section{To cite this version:}

Stanislav Obruca, Ivana Marova, Ondrej Snajdar, Ludmila Mravcova, Zdenek Svoboda. Production of poly(3-hydroxybutyrate-3-hydroxyvalerate) by from waste rapeseed oil using propanol as a precursor of 3-hydroxyvalerate. Biotechnology Letters, 2010, 32 (12), pp.1925-1932. 10.1007/s10529-010-0376-

8. hal-00614504

\author{
HAL Id: hal-00614504 \\ https://hal.science/hal-00614504
}

Submitted on 12 Aug 2011

HAL is a multi-disciplinary open access archive for the deposit and dissemination of scientific research documents, whether they are published or not. The documents may come from teaching and research institutions in France or abroad, or from public or private research centers.
L'archive ouverte pluridisciplinaire $\mathbf{H A L}$, est destinée au dépôt et à la diffusion de documents scientifiques de niveau recherche, publiés ou non, émanant des établissements d'enseignement et de recherche français ou étrangers, des laboratoires publics ou privés. 


\title{
Section: Microbial and Enzyme Technology
}

\author{
Production of poly(3-hydroxybutyrate-co-3-
}

hydroxyvalerate) by Cupriavidus necator from

waste rapeseed oil using propanol as a

precursor of 3-hydroxyvalerate

Stanislav Obruca ${ }^{1 *}$, Ivana Marova ${ }^{1}$, Ondrej Snajdar $^{1}$, Ludmila Mravcova $^{2}$, Zdenek Svoboda $^{3}$

${ }^{1}$ Brno University of Technology, Faculty of Chemistry, Department of Food

Chemistry and Biotechnology, Purkynova 118, 61200 Brno, Czech Republic

${ }^{2}$ Brno University of Technology, Faculty of Chemistry, Department of Chemistry and Technology of Environmental Protection, Purkynova 118, 61200 Brno,

Czech Republic

${ }^{3}$ Research Institute of Brewing and Malting, Malting Institute Brno, Mostecka 7, 61400 Brno, Czech Republic

Phone: +420 541 149 321; Fax: +420 541 211 697; E-mail:

Stana.O@seznam.cz. 
Keywords Cupriavidus necator, Polyhydroxyalkanoates, Propanol, Stress

conditions, Waste edible oils

\begin{abstract}
Waste rapeseed oil is a useful substrate for polyhydroxyalkanoates (PHA) production employing Cupriavidus necator H16. In fed-batch mode, we obtained biomass and PHA yields of 138 and $105 \mathrm{~g} \mathrm{l}^{-1}$, respectively. Yield coefficient and volumetric productivity were $0.83 \mathrm{~g}$ PHA per g oil and $1.46 \mathrm{~g} \mathrm{l}^{-1} \mathrm{~h}^{-1}$, respectively. Propanol at $1 \%(\mathrm{v} / \mathrm{v})$ enhanced both PHA and biomass formation significantly and, furthermore, resulted in incorporation of 3-hydroxyvalerate units into PHA structure. Thus, propanol can be used as an effective precursor of 3-hydroxyvalarete for production of poly(3-hydroxybutyrate-co-3-hydroxyvalerate) copolymer. During the fed-batch cultivation, propanol concentration was maintained at $1 \%$ which resulted in $8 \%$ content of 3-hydroxyvalerate in copolymer.
\end{abstract}

\title{
Introduction
}

Polyhydroxyalkanoates (PHA) are polyesters of hydroxyacids, which are accumulated in bacterial cells in form of intracellular granules. Bacteria use PHA as carbon, energy and reducing power storage materials. Due to their mechanical properties, PHA have attracted much attention as biodegradable alternative to traditional petrochemical plastics (Kessler and Witholt 1999). The member of PHA family, copolymer poly(3-hydroxybutyrate-co-3-hydroxyvalerate) $[\mathrm{P}(\mathrm{HB}-$ co-HV)], is one of the best characterized PHA copolymers because of its high commercial potential. Incorporation of 3-hydroxyvalerate (3-HV) units into PHA structure reduces the hardness, crystallinity and melting point of material as 
compared to homopolymer of 3-hydroxybutyrate (3-HB), poly(3-

hydroxybutyrate) (PHB). Therefore, copolymer $\mathrm{P}(\mathrm{HB}-c o-\mathrm{HV})$ possesses better mechanical properties and processability (Du et al. 2001).

In spite of many satisfactory properties of PHA, their commercial applications have been limited by their high price. One approach to reduce the cost of PHA production is to use inexpensive carbon sources, such as plant oils, for their production. In contrast to other carbon sources, the theoretical yield coefficients of PHA production from plant oils are over $1 \mathrm{~g}$ PHA per g plant oil, since they comprise a much higher number of carbon atoms per weight (Kahar et al. 2003).

Waste edible oils from the food industry and food service industry are recovered as industrial wastes. They can be converted into feed for animals, fatty acids, soap or bio-diesel. Nevertheless, waste oils are largely destroyed in incinerators or are abandoned in the environment, which causes problems with waste management or water pollution (Taniguchi et al. 2003). These problematic waste oils could be used as cheap substrates for microbial production of PHA highly valuable environmentally-friendly materials.

This report describes production of $\mathrm{PHB}$ and $\mathrm{P}(\mathrm{HB}-\mathrm{co}-\mathrm{HV})$ from waste rapeseed oil employing Cupriavidus necator H16. In our previous work we reported that exposition of $C$. necator to controlled ethanol or $\mathrm{H}_{2} \mathrm{O}_{2}$ stress enhances PHA accumulation in cells (Obruca et al. 2010a, Obruca et al. 2010b). Therefore, we decided to test also other aliphatic alcohols as stress factors enhancing PHA yields. Finally, we performed fed-batch cultivation of C. necator in laboratory fermentor under controlled stress conditions using waste rapeseed oil as a carbon substrate. 


\section{Material and Methods}

\section{Microorganism}

Cupriavidus necator H16 (CCM 3726) purchased from Czech Collection of Microorganisms, Brno, Czech Republic, was used in all experiments.

\section{Culture media}

Nutrient broth (NB) medium was used for inoculum development. NB consisted of $10 \mathrm{~g}$ peptone, $10 \mathrm{~g}$ beef extract, $5 \mathrm{~g} \mathrm{NaCl}$ in 11 distilled water. Mineral salt (MS) medium was used in all production experiments. MS medium contained $3 \mathrm{~g}\left(\mathrm{NH}_{4}\right)_{2} \mathrm{SO}_{4}, 1 \mathrm{~g} \mathrm{KH} \mathrm{KO}_{4}, 11.1 \mathrm{~g} \mathrm{Na}_{2} \mathrm{HPO}_{4} .12 \mathrm{H}_{2} \mathrm{O}, 0.2 \mathrm{~g} \mathrm{MgSO}_{4}, 1$ $\mathrm{ml}$ microelement solution and 11 of distilled water. The microelement solution was composed of $9.7 \mathrm{~g} \mathrm{FeCl}_{3}, 7.8 \mathrm{~g} \mathrm{CaCl}_{2}, 0.156 \mathrm{~g} \mathrm{CuSO}_{4} .5 \mathrm{H}_{2} \mathrm{O}, 0.119 \mathrm{~g} \mathrm{CoCl}_{2}$, $0.118 \mathrm{~g} \mathrm{NiCl}_{2}, 0.062 \mathrm{~g} \mathrm{CrCl}_{2}$ in $110.1 \mathrm{M} \mathrm{HCl}$. Plant edible oils (20 $\mathrm{g}$ in 11 of medium) were used as carbon sources in production media. Oils, salt solution and microelement solution were sterilised separately at $121^{\circ} \mathrm{C}$ for $25 \mathrm{~min}$ and then aseptically reconstituted at room temperature prior to inoculation. The $\mathrm{pH}$ was adjusted to 7.0 using $2 \mathrm{M} \mathrm{NaOH} / \mathrm{HCl}$. Pure oils were purchased in supermarkets; waste frying rapeseed and sunflower oils were obtained locally.

\section{Cultivation in flasks}

The microorganism was grown in NB medium at $200 \mathrm{rpm}, 30^{\circ} \mathrm{C}$ for $24 \mathrm{~h}$. For production cultivation, $100 \mathrm{ml} \mathrm{MS}$ medium with oil $\left(20 \mathrm{~g} \mathrm{l}^{-1}\right)$ was held in 300 $\mathrm{ml}$ Erlenmeyer flasks and inoculated with $5 \mathrm{ml}$ culture. The flasks were shaken at (200 rpm and at $30^{\circ} \mathrm{C}$ ). 


\section{Fed-batch cultivation in fermentor}

Fermentor vessel (2 1, BioFlo Celligen 115, New Brunswick) containing 1.2 $1 \mathrm{MS}$ medium and waste rapeseed oil $\left(20 \mathrm{~g} \mathrm{l}^{-1}\right)$ was inoculated with $60 \mathrm{ml} 24 \mathrm{~h}$ culture grown on NB medium. The temperature was set at $30^{\circ} \mathrm{C}, \mathrm{pH}$ was maintained at 7 by $0.5 \mathrm{M} \mathrm{NaOH} / \mathrm{H}_{2} \mathrm{SO}_{4}$. The dissolved oxygen (DO) concentration was monitored by an $\mathrm{O}_{2}$ electrode. $\mathrm{DO}$ value was maintained at the level of $50 \%$ to air saturation by varying the agitation speed and/or air flow rate automatically.

\section{Analytical procedures}

To measure biomass concentration (expressed as cell dry weight) and PHA content in cells, samples $(10 \mathrm{ml})$ were centrifuged and the cells were washed with $5 \%(\mathrm{v} / \mathrm{v})$ Triton $\mathrm{X}(10 \mathrm{ml})$ and then distilled water. The biomass concentration was analyzed as reported previously (Obruca et al. 2010b). PHA content in cells and monomer composition of PHA were analyzed as methyl esters of particular 3hydroxyacids by gas chromatography as reported by Brandl et al. (1988). Residual biomass was defined as biomass minus PHA concentration.

The concentration of oil in the medium was estimated according to Kahar et al. (2004); $\left(\mathrm{NH}_{4}\right)_{2} \mathrm{SO}_{4}$ was analyzed spectrophotometrically using Nessler's reagent. Propanol was measured as amount of NADH $\left(\mathrm{A}_{340 \mathrm{~nm}}\right)$ formed after 5 min treatment of sample $(100 \mu \mathrm{l}$ of cultivation medium diluted to $1 \mathrm{ml}$ with $100 \mathrm{mM}$ phosphate buffer pH 7.0) with 30 units alcohol dehydrogenase (Sigma). 


\section{RESULTS AND DISCUSSION}

\section{PHB production from various oils}

To investigate the ability of Cupriavidus necator $\mathrm{H} 16$ to utilize plant oils and produce PHA, we performed cultivation of this bacterial strain on selected oils of various origins (Tab. 1). Growth of the bacterial culture and production of PHB homopolymer were observed with all tested plant oils. The highest yields were reached using waste frying oils. During the frying process, the oil undergoes some changes - fatty acid composition is slightly changed, the concentration of free fatty acids is enhanced and also some components of fried food such as proteins, lipids or carbohydrates migrate to the oil (Matthäus 2007). It is likely that these changes were beneficial for bacterial growth and PHB accumulation.

Although waste oils seem to be a promising feedstock for PHA production, only a few authors have reported PHA production on these substrates. Taniguchi et al. (2003) reported PHA production from waste sesame oil employing $C$. necator; the highest achieved PHB yield was $4.6 \mathrm{~g} \mathrm{l}^{-1}$. Chan et al. (2006) studied PHA production from various plant oils including waste oil using Pseudomonas aeruginosa, but PHA content in cells was only about $5 \%$ of dry cell weight. Finally, Vidal-Mas et al. (2001) cultivated Pseudomonas aeruginosa on waste frying oil and reached PHA yields of $3 \mathrm{~g} \mathrm{l}^{-1}$. Nevertheless, in this work we obtained PHB yields which were significantly higher than those reported in literature. The highest PHB yields were achieved on waste rapeseed oil coming from the university canteen and, therefore, this oil was used as a carbon substrate in further cultivations. 


\section{Introduction of stress conditions by alcohols}

In our previous work we observed that exposition of $C$. necator to ethanol significantly enhanced PHB accumulation in cells (Obruca et al. 2010b). Briefly, ethanol was metabolized via oxidation while reduced coenzymes $\mathrm{NAD}(\mathrm{P}) \mathrm{H}$ were formed. The final product of ethanol metabolization was acetyl-CoA, the key substrate of PHB biosynthesis. Reduced coenzymes both inhibited Krebs cycle and served as co- substrates of acetoacetyl-CoA reductase - the second enzyme of PHB biosythetic pathway. As the consequence of Krebs cycle inhibition, the flux of acetyl-CoA into PHB biosynthetic pathway was increased. Simultaneously, less free CoA, which inhibited $\beta$-ketothiolase - the first enzyme of PHB biosynthesis, was formed.

We expected that also application of other alcohols may have induced similar response of the culture resulting in enhanced PHA yields. Therefore, we added methanol ethanol and propanol into cultivation media at various times of cultivation (Table 2).

In terms of biomass as well as PHA yields, the most efficient was addition of alcohols after $24 \mathrm{~h}$. The alcohols not only enhanced PHA accumulation in comparison with the control culture but, surprisingly, also increased bacterial growth. The more non-polar alcohol was applied, the more pronounced growth was observed. The explanation of such an effect could be that the alcohols supported solubilization of triacylglycerols, which made them more susceptible to extracellular lipases. This is likely to have increased concentrations of products of lipolysis (glycerol and fatty acids) in medium that could support bacterial growth. 
Ethanol and propanol enhanced PHA production significantly. In addition, metabolism of propanol resulted in incorporation of 3-hydroxyvalerate into PHA, which could improve mechanical properties of produced material. For instance, incorporation of $10 \% 3$-hydroxyvalerate increases elongation to break from $3 \%$ (homopolymer PHB) to $20 \%$ (copolymer P(HB-co-HV)) (Kessler and Withholt 1999).

To our knowledge, the application of propanol as a precursor of 3hydroxyvalerate in $\mathrm{P}(\mathrm{HB}-\mathrm{co}-\mathrm{HV})$ has not been reported so far. In comparison with other commonly used precursors of 3-hydroxyvalerate, such as propionate or valerate, propanol has several advantages. Apart from the enhancement of PHA yields and the support of bacterial growth on oils, propanol is also much cheaper. In Table 3, propanol is compared with other commonly used precursors of 3-HV.

We assume that the metabolism of propanol in $C$. neactor is similar to that of ethanol (Obruca et al. 2010b). Thus, propanol is oxidized and transformed into propionyl-CoA. During oxidation, reduced coenzymes are formed, which again supports PHA synthesis in the same way as in ethanol. Further, propionyl-CoA is coupled with acetyl-CoA in reaction catalyzed by $\beta$-ketothiolase. $\beta$-ketothiolase encoded by the gene $p h b A$ is specific only for acetyl-CoA, therefore, this step must be catalyzed by the enzyme encoded by the gene $b k t B$ which is placed out of phaCAB operon of $C$. necator (Slater et al. 1998). NADPH-dependent stereospecific reduction of 3-ketovaleryl-CoA could be catalyzed by acetoacetylCoA reductase. The final step of copolymer synthesis is catalyzed by PHB synthase which is, thanks to its low substrate specificity, able to build 3 hydroxyvalerate units into PHA structure (Fig. 1).

The highest growth and PHA production was with $1 \%(\mathrm{v} / \mathrm{v})$ propanol but the highest content of 3-HV in PHA was with $0.75 \%$ (v/v) propanol. (Table 4). 
Controlled application of propanol as stress factor not only enhanced total PHB yields but also increased PHB content in cells. This would reduce the costs of PHB recovery, since PHB content in cells strongly affects the efficiency and the cost of down-stream processing (Lee and Choi 1999).

\section{PHA production in fed-batch mode}

Because production of $\mathrm{P}(\mathrm{HB}-\mathrm{co}-\mathrm{HV})$ from waste rapeseed oil using propanol as a stress agent seemed to be a prosing strategy, we performed fedbatch cultivation in a laboratory fermentor (Fig. 2).

After $72 \mathrm{~h}$ the cell dry weight was $138 \mathrm{~g} \mathrm{l}^{-1}$. Cells contained $76 \%$ PHA with $8 \%$ content of $3-\mathrm{HV}$. Total yield of PHA was $105 \mathrm{~g} \mathrm{l}^{-1}$. Volumetric productivity yield was $1.46 \mathrm{~g} \mathrm{l}^{-1} \mathrm{~h}^{-1}$ and yield coefficient was $0.83 \mathrm{~g}$ PHA per $\mathrm{g}$ oil. To our knowledge, these yields achieved are among the highest reported for PHA production from oils. Kahar et al. (2004) performed fed-batch cultivation of C. necator on soybean oil; yield coefficient and volumetric productivity yield were $0.76 \mathrm{~g}$ PHA per g oil and $1 \mathrm{~g} \mathrm{l}^{-1} \mathrm{~h}^{-1}$, respectively. Thus, we gained better yields and, moreover, we only used cheap waste oil instead of pure oil.

\section{Conclusion}

We have shown that utilization of waste edible oils is a promising strategy facilitating an economically feasible process of PHA production. Waste oils are lower in price as compared to other pure substrates. Moreover, problematic waste would be transformed into high value product. In fed-batch mode of cultivation, we gained high yield coefficient and volumetric productivity yield 0.83 g PHA per g oil and $1.46 \mathrm{~g} \mathrm{l}^{-1} \mathrm{~h}^{-1}$, respectively. Furthermore, we suggest propanol as a 
novel precursor of 3-hydroxyvalerate for $\mathrm{P}(\mathrm{HB}-\mathrm{co}-\mathrm{HV})$ copolymer production. Apart from the fact that propanol is built into PHA structure, which improves mechanical properties of material, it also enhances PHA yields and supports bacterial growth on oils.

Ackonowledgements This work was supported by projects MSM 0021630501 and CZ.1.05/2.1.00/01.0012 of the Czech Ministry of Education

\section{References}

Brandl H, Gross RA, Lenz RW, Fuller RC (1988) Pseudomonas oleovorans as a source of poly(beta-hydroxyalkanoates) for potential application as a biodegradable polyester. Appl Environ Microb 54:1977-1982.

Chan PL, Yu V, Wai L, Yu HF (2006) Production of medium-chain-length polyhydroxyalkanoates by Pseudomonas aeruginosa with fatty acids as alternative carbon sources. Appl Biochem Biotech 129:933-941

Du GC, Chen J, Yu J, Lun S (2001) Feeding strategy of propionic acid for production of poly(3-hydroxybutyrate-co-3-hydroxyvalerate) with Ralstonia eutropha. Biochem Eng J $8: 103-110$

Kahar P, Tsuge T, Taguchi K, Doi Y (2004) High yield production of polyhydroxyalkanoates from soybean oil by Ralstonia eutropha and its recombinant strain. Pol Degrad Stabil, $83: 79-86$

Kessler B, Witholt B (1999) Poly(3-hydroxyalkanoates) In Flickinger MC, Drew SW (eds) Encyclopedia of Bioprocess Technology - Fermentation, Biocatalysis and Bioseparation. John Wiley, New York, , pp. 2024-2040

Lee SY, Choi J (1999) Effect of fermentation performance on the economics of poly-(3hydroxybutyrate) production by Alcaligenes latus. Pol Degrad Stabil, 59:387-393

Matthäus B (2007) Use of palm oil for frying in comparison with other high-stability oils. Eur J Lipid Sci Technol 109:400-409 
Obruca S, Marova I, Svoboda Z, Mikulikova R (2010a) Use of controlled exogenous stress for improvement of poly(3-hydroxybutyrate) production in Cupriavidus necator. Folia Microbiol 55:17-22

Obruca S, Marova I, Stankova M, Mravcova L, Svoboda Z (2010b) Effect of ethanol and hydrogen peroxide on poly(3-hydroxybutyrate) biosynthetic pathway in Cupriavidus necator H16, World J Microb Biot 26:1261-1267

Slater S, Houmiel KL, Tran M, Mitsky TA, Taylor NB, Padgette SR, Gruys KJ (1998)

Multiple beta-ketothiolases mediate poly(beta-hydroxyalkanoate) copolymer synthesis in Ralstonia eutropha. J Bacteriol 180:1979-1987

Taniguchi I, Kagotani K, Kimura Y (2003) Microbial production of poly(hydroxyalkanoates) from waste edible oils. Green Chem 5:545-548

Vidal-Mas J, Resina-Pelfort O, Haba E, Comas J, Manresa A, Vives-Rego J (2001) Rapid flow cytometry - Nile red assesment of PHA cellular content and heterogeneity in cultures of Pseudomonas aeruginosa 47T2 (NCIB 40044) grown in waste frying oil. Anton Leeuw Int J G 80:57-63

\section{Tables}


Table 1 Growth and PHB production of $C$. necator $\mathrm{H} 16$ on various oils ${ }^{\mathrm{a}}$

\begin{tabular}{|c|c|c|c|}
\hline Oil & $\begin{array}{c}\text { Biomass } \\
{\left[\text { g. }{ }^{-1}\right]}\end{array}$ & $\begin{array}{l}\text { PHB } \\
{\left[\text { g. }{ }^{-1}\right]}\end{array}$ & $\begin{array}{c}\text { PHB } \\
{\left[\begin{array}{ll}\% / w & w\end{array}\right]}\end{array}$ \\
\hline Olive & $8.1 \pm 0.2$ & $3.3 \pm 0.3$ & 40 \\
\hline Corn & $10.6 \pm 0.6$ & $4.4 \pm 0.4$ & 40 \\
\hline Soybean & $7.5 \pm 0.4$ & $2.0 \pm 0.1$ & 28 \\
\hline Sunflower & $9.4 \pm 0.2$ & $4.6 \pm 0.4$ & 49 \\
\hline Rapeseed & $9.5 \pm 0.4$ & $4.8 \pm 0.4$ & 50 \\
\hline Waste - Household (sunflower) & $10.3 \pm 0.6$ & $5.8 \pm 0.4$ & 57 \\
\hline Waste - University canteen (rapeseed) & $12.8 \pm 0.5$ & $7.7 \pm 0.4$ & 60 \\
\hline Waste - Restaurant (sunflower) & $11.4 \pm 0.5$ & $6.7 \pm 0.1$ & 59 \\
\hline Waste - Chips manufactory (rapeseed) & $12.2 \pm 0.6$ & $6.8 \pm 0.5$ & 55 \\
\hline
\end{tabular}

${ }^{\mathrm{a}}$ Cultivation conditions: MS medium, oil $20 \mathrm{~g} \mathrm{l}^{-1}$, Erlenmeyer flasks, $30^{\circ} \mathrm{C}, 200 \mathrm{rpm}$, samples were withdrawn at the $72^{\text {nd }}$ hour of cultivation.

Results are in form: mean \pm standard deviation, cultivations were performed in triplicate and analyzed in triplicate as well.

Table 2 Biomass and PHA production after alcohols applications ${ }^{\mathrm{a}}$. 


\begin{tabular}{|c|c|c|c|c|c|c|}
\hline & $\begin{array}{c}\text { Time of } \\
\text { application }\end{array}$ & $\begin{array}{c}\text { Biomass } \\
{\left[\text { g. }^{-1}\right]}\end{array}$ & $\begin{array}{l}\text { PHA } \\
{\left[\text { g. }{ }^{-1}\right]}\end{array}$ & $\begin{array}{c}\text { PHA } \\
{[\% \mathrm{w} / \mathrm{w}]}\end{array}$ & $\begin{array}{c}\text { 3-HB }^{\mathbf{b}} \\
{[\%]}\end{array}$ & $\begin{array}{c}\text { 3-HV } \\
{[\%]}\end{array}$ \\
\hline \multirow{3}{*}{ Methanol } & 24 & $12.1 \pm 0.8$ & $8.3 \pm 0.2$ & 69 & 100 & 0 \\
\hline & 48 & $10.5 \pm 0.4$ & $5.2 \pm 0.5$ & 50 & 100 & 0 \\
\hline & 60 & $10.3 \pm 0.5$ & $6.7 \pm 0.1$ & 65 & 100 & 0 \\
\hline \multirow{3}{*}{ Ethanol } & 24 & $13.0 \pm 0.5$ & $10.4 \pm 0.8$ & 80 & 100 & 0 \\
\hline & 48 & $12.3 \pm 0.7$ & $8.2 \pm 0.2$ & 67 & 100 & 0 \\
\hline & 60 & $10.1 \pm 1.3$ & $5.4 \pm 0.1$ & 54 & 100 & 0 \\
\hline \multirow{3}{*}{ Propanol } & 24 & $14.7 \pm 0.3$ & $11.7 \pm 0.7$ & 80 & 91 & 9 \\
\hline & 48 & $12.7 \pm 0.9$ & $7.8 \pm 0.7$ & 61 & 97 & 3 \\
\hline & 60 & $11.3 \pm 0.2$ & $7.1 \pm 0.4$ & 63 & 97 & 3 \\
\hline \multicolumn{2}{|c|}{ Control } & $11.2 \pm 0.6$ & $5.9 \pm 0.4$ & 53 & 100 & 0 \\
\hline
\end{tabular}

${ }^{a}$ Cultivation conditions: MS medium, oil $20 \mathrm{~g} \mathrm{l}^{-1}$, Erlenmeyer flasks, $30^{\circ} \mathrm{C}, 200 \mathrm{rpm}$, samples were withdrawn at $84 \mathrm{~h}$. Alcohol concentration in medium was $1 \%(\mathrm{v} / \mathrm{v})$ in each case.

${ }^{\mathrm{b}}$ Molar content $(\%)$ of particular monomer in polymer

Results are in form: mean \pm standard deviation, cultivations were performed in triplicate and analyzed in triplicate as well.

Table 3 Production of $\mathrm{P}(\mathrm{HB}-\mathrm{co}-\mathrm{HV})$ on waste rapeseed oil using selected precursors of $3-\mathrm{HV}^{\mathrm{a}}$. 


\begin{tabular}{|c|c|c|c|c|c|}
\hline Precursor & $\begin{array}{c}\text { Biomass } \\
{\left[\text { g. }^{-1}\right]}\end{array}$ & $\begin{array}{c}\text { PHA } \\
{\left[\text { g. }^{-1}\right]}\end{array}$ & $\begin{array}{c}\text { PHA } \\
{[\% \mathrm{w} / \mathrm{w}]}\end{array}$ & $\begin{array}{c}\text { 3-HB } \\
{[\%]}\end{array}$ & $\begin{array}{c}\text { 3-HV } \\
{[\%]}\end{array}$ \\
\hline Propanol (1 \% v/v) & $14.7 \pm 0.3$ & $11.7 \pm 0.7$ & 80 & 91 & 9 \\
\hline Propionate $\left(5 \mathrm{~g} \mathrm{l}^{-1}\right)$ & $14.1 \pm 0.3$ & $7.3 \pm 0.8$ & 52 & 87 & 13 \\
\hline Valerate $\left(5 \mathrm{~g} \mathrm{l}^{-1}\right)$ & $12.1 \pm 0.5$ & $6.5 \pm 0.2$ & 53 & 82 & 18 \\
\hline Control & $11.2 \pm 0.6$ & $5.9 \pm 0.4$ & 53 & 100 & 0 \\
\hline
\end{tabular}

${ }^{\mathrm{a}}$ Cultivation conditions: MS medium, oil $20 \mathrm{~g} \mathrm{l}^{-1}$, Erlenmeyer flasks, $30^{\circ} \mathrm{C}, 200 \mathrm{rpm}$, samples were withdrawn after $84 \mathrm{~h}$. Precursors were applied at $24 \mathrm{~h}$. Propanol concentration in medium was set at $1 \%(\mathrm{v} / \mathrm{v})$, propionate and valerate was $5 \mathrm{~g} \mathrm{l}^{-1}$.

${ }^{\mathrm{b}}$ Molar content (\%) of particular monomer in polymer.

Results are in form: mean \pm standard deviation; cultivations were performed in triplicate and analyzed in triplicate as well.

Table 4 Optimization of $\mathrm{PrOH}$ concentration ${ }^{\mathrm{a}}$. 


\begin{tabular}{cllllr}
\hline $\begin{array}{c}\text { Propanol } \\
{[\% \mathbf{v} / \mathbf{v}]}\end{array}$ & Biomass & PHA & PHA & 3-HB & 3-HV \\
\hline $\mathbf{0 . 5}$ & $12.3 \pm 0.7$ & $7.8 \pm 0.1$ & 63 & 94 & 6 \\
$\mathbf{0 . 7 5}$ & $12.9 \pm 0.4$ & $9.1 \pm 1.0$ & 70 & 86 & 14 \\
$\mathbf{1}$ & $13.7 \pm 0.2$ & $10.8 \pm 0.3$ & 79 & 89 & 11 \\
$\mathbf{1 . 2 5}$ & $13.0 \pm 0.1$ & $8.7 \pm 0.5$ & 67 & 90 & 10 \\
$\mathbf{1 . 5}$ & $12.1 \pm 0.2$ & $8.3 \pm 0.7$ & 69 & 91 & 9 \\
\hline Control & $11.2 \pm 0.7$ & $6.4 \pm 0.6$ & 58 & 100 & 0 \\
\hline
\end{tabular}

${ }^{a}$ Cultivation conditions: MS medium, oil $20 \mathrm{~g} \mathrm{l}^{-1}$, Erlenmeyer flasks, $30^{\circ} \mathrm{C}, 200 \mathrm{rpm}$, samples were withdrawn at $84 \mathrm{~h}$. Propanol was added at $24 \mathrm{~h}$.

b Molar content $(\%)$ of particular monomer in polymer.

Results are in form: mean \pm standard deviation, each cultivation was performed in triplicate and analyzed in triplicate as well.

\section{List of figure captions}


Fig. 1 Proposed mechanism of metabolization of propanol by C. necator $\mathrm{H} 16$ and its incorporation into $\mathrm{P}(\mathrm{HB}-\mathrm{co}-\mathrm{HV})$ copolymer structure.

Fig. 2 PHA production form waste rapeseed oil in fed-batch mode. Propanol was added at $18 \mathrm{~h}$ and after that its concentration was maintained at $1 \%(\mathrm{v} / \mathrm{v}),\left(\mathrm{NH}_{4}\right)_{2} \mathrm{SO}_{4}$ was maintained at $3 \mathrm{~g} \mathrm{l}^{-1}$ until $30 \mathrm{~h}$ when nitrogen feeding was stopped to induce nitrogen limitation. The concentration of carbon source - waste rapeseed oil was kept at $20 \mathrm{~g} \mathrm{l}^{-1}$. $\mathbf{a}=$ biomass, PHA and residual biomass developments. $\mathbf{b}=$ ammonium sulfate and oil concentrations. $\mathbf{c}=$ propanol concentration and 3HV content in the copolymer. Each sample was analyzed in triplicate. 
$\mathbf{a}$

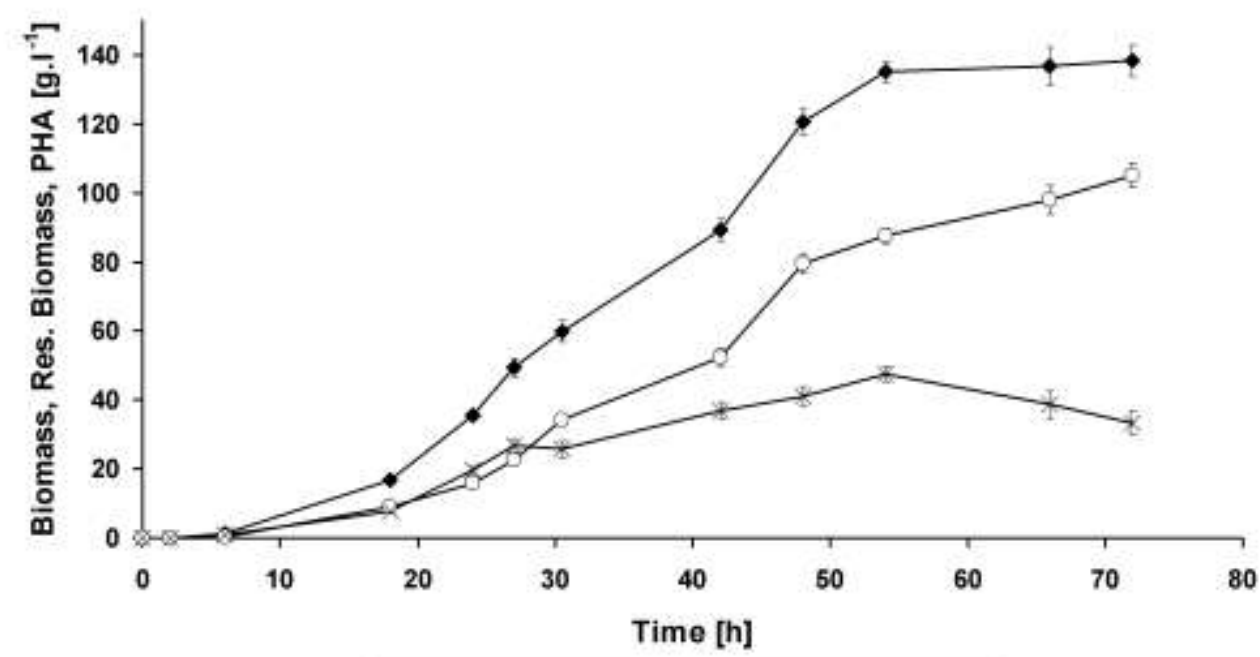

$\leftarrow$ Biomass $\approx-$ PHA $*$ Residual biomass

b

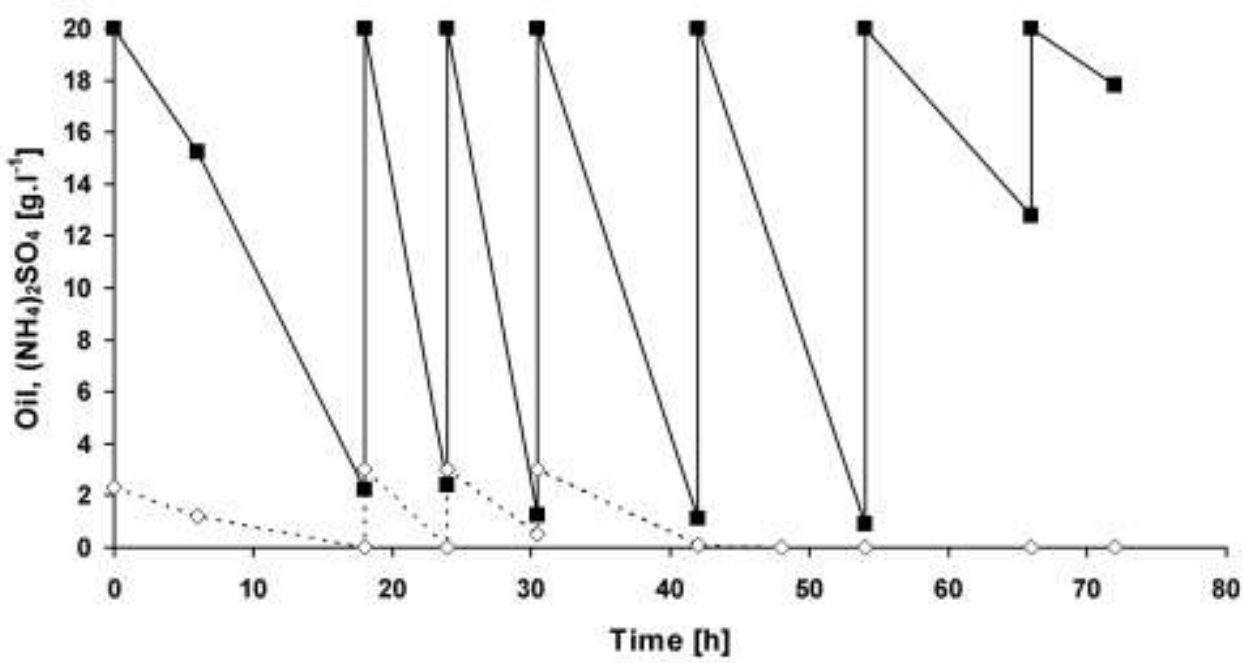

$-\infty-\mathrm{Oil} \cdot \cdots \cdot(\mathrm{NH} 4) 2 \mathrm{SO} 4$

c

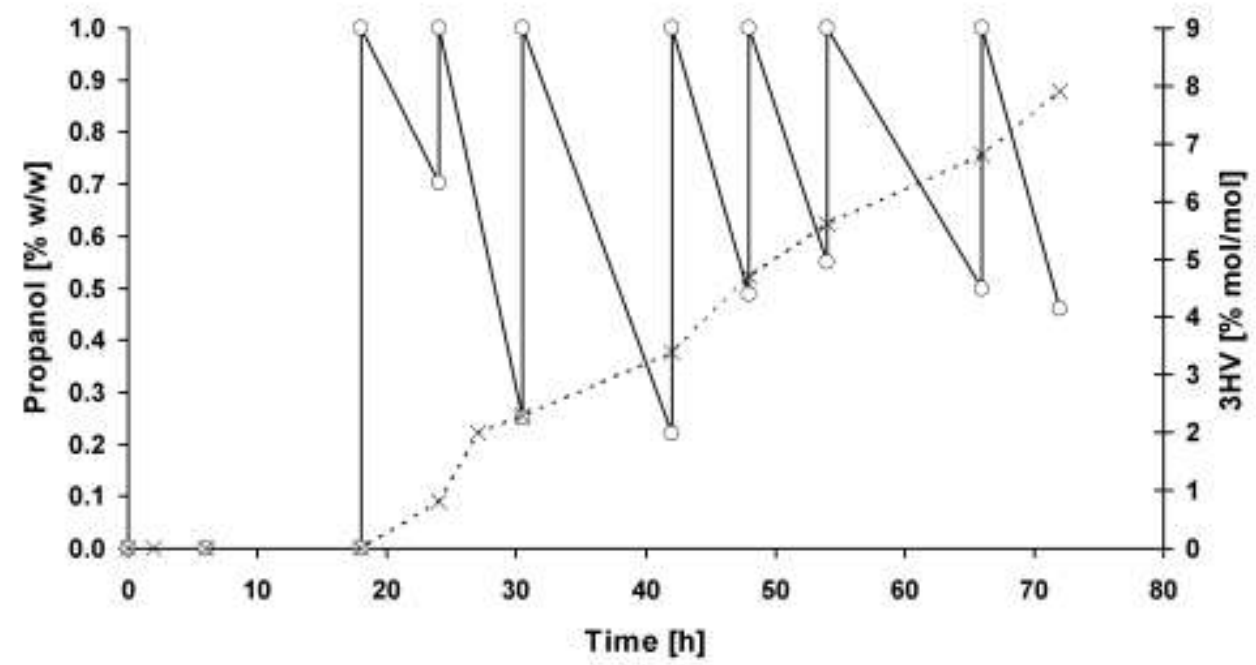

$-\circ$ Propanol $\cdot x \cdot 3 \mathrm{HV}$ 


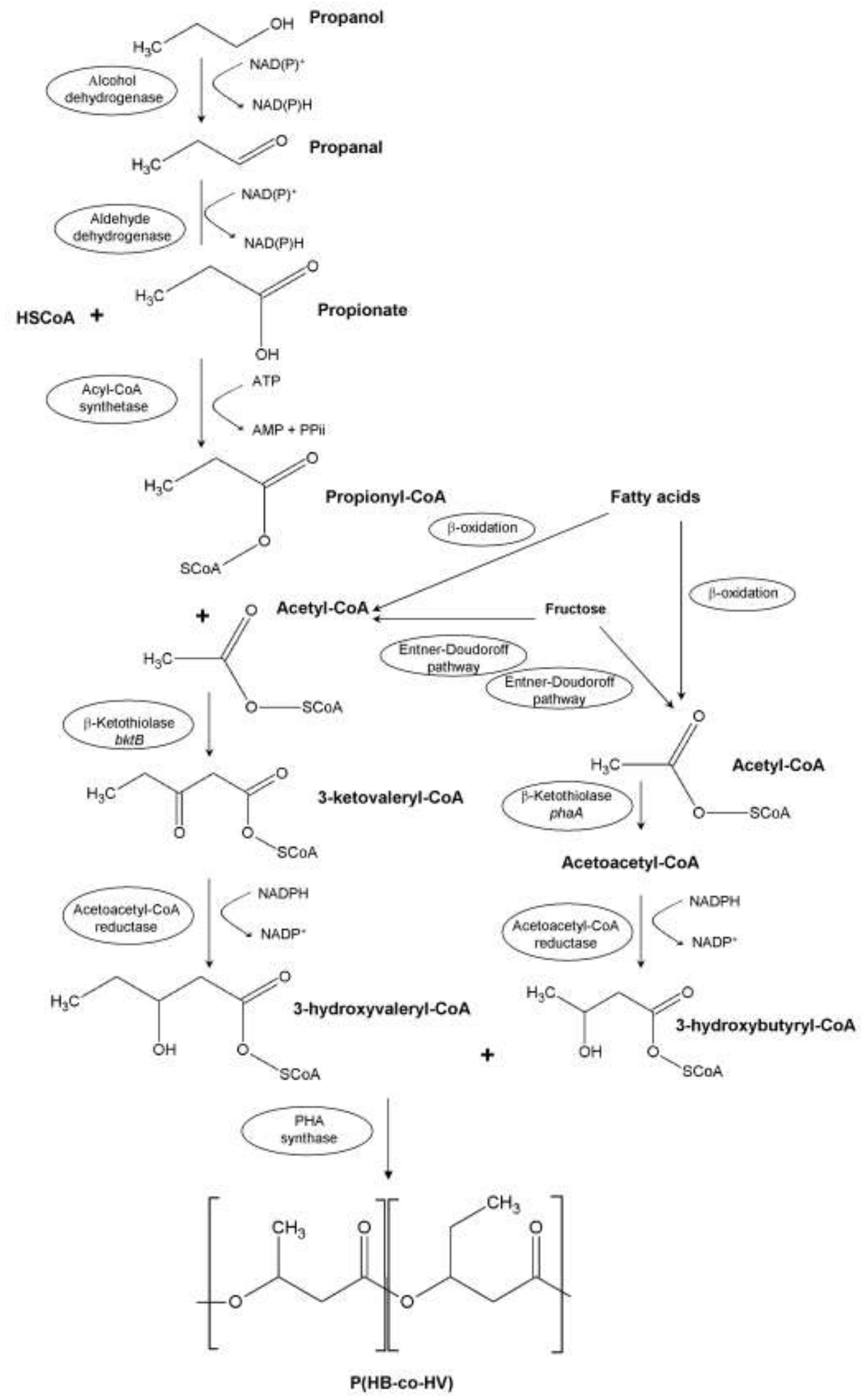

